\title{
The role of the seed sector in Italy for a modern and competitive agriculture
}

\author{
Marco Nardi \\ ASSOSEMENTI (Italian Seed Association), Bologna, Italy
}

\begin{abstract}
The high number of seed companies that are active on the Italian market provides our agriculture with the most appropriate varieties. Italy is particularly suited for growing seed crops: thanks to its favourable environmental conditions and also to the high level of professional skills of companies and farmers, Italy plays a leading role in the multiplication and export of vegetables, rice and sugarbeet seeds. In many cases, seeds grown in Italy are exported for conditioning and then re-imported for distribution to the end users. In 2014 the annual turnover for seed sales in Italy was approximately EUR 680-700 million, at wholesale level and excluding the incidence of chemical seed treatment. The difference between the value of seed imports and exports has been negative in the last few years of an average amount of approximately EUR 100 million. At the moment there are about 300 seed companies trading on the Italian market (220 for agricultural plant species and 80 for vegetable species). Seed multiplication is also a great income opportunity for farmers: every year approximately 15,000 Italian farmers devote around 220,000 ha to grow seed crops.

The use of high quality seed today represents not only a simple means to start a new cultivation, with a healthy, well identified and traced product, but an efficient way to transfer plant breeding results to farmers, in order to cope with the need of innovation and sustainability. Through the purchase and planting of certified seeds farmers support and strengthen variety research and innovation.
\end{abstract}

Correspondence: Marco Nardi (former General Secretary), ASSOSEMENTI, via dell'Industria 33, 40138 Bologna, Italy.

E-mail: nestplace35@gmail.com

Key words: Seeds; seed industry; innovation; plant breeding; economic resources.

Acknowledgements: the author would like to thank Enrico Noli of the Seed Research and Testing Laboratory (LaRAS) of the University of Bologna for his suggestions and for revising the text.

Conference presentation: SIA XLIV Congress, Bologna, 2015.

Received for publication: 2 February 2016.

Revision received: 24 March 2016.

Accepted for publication: 1 April 2016.

(C) Copyright M. Nardi, 2016

Licensee PAGEPress, Italy

Italian Journal of Agronomy 2016; 11:761

doi:10.4081/ija.2016.761

This article is distributed under the terms of the Creative Commons Attribution Noncommercial License (by-nc 4.0) which permits any noncommercial use, distribution, and reproduction in any medium, provided the original author(s) and source are credited.

\section{Introduction}

Seeds, as well as any other asexual reproduction material, are the first critical link in the agri-food production chain and represent the starting point for growing crops intended to produce food, feed and other bio-based products and energy. The properties of seeds are essential to obtain a high yield and quality. The evolution of both the private and public seed sectors, alongside with the progress of genetic research and the technological advancement in seed production and processing, greatly contributed to the development of farming and to the value of the agri-food production chain.

The seed sector includes plant breeding, seed growing, seed conditioning and seed marketing and distribution, which are rarely carried out by a single firm (the so called integrated company). Seed companies in Italy are mainly engaged in seed growing, conditioning and marketing wilst only a few private firms carry out some traditional plant breeding, in any case, economic resources available for this activity are limited. Private/public partnership in variety research has been important in the past and should have a crucial role in the future.

The aim of this work is to describe the main traits of the Italian seed sector and the issues to be faced maintaining this role, for the wealth of the whole Italian agri-food production.

\section{Results and discussion}

\section{The Italian seed industry}

As far as seed activity is concerned, today Italy can be pictured as follows: a land where it is possible to multiply high quality seeds of many plant species, thanks to the favourable climatic conditions and the skills of all those involved in the production chain; a country where seed research and plant breeding are limited, both at private and public levels, apart from some restricted sectors; a market where all the world's leading seed companies are present to promote and sell their new varieties to feed a very intensive and innovation oriented farming.

\section{Some data to set the framework}

In Italy there are about 300 active seed companies (which are regularly authorized by the local Regional Phytosanitary Service according to the fundamental seed law n. 1196/71, to process and condition seeds; Italian Regulation, 1971); of them, about 220 deal with seeds of agricultural plant species (cereals, herbages, sugarbeet and oilseeds), which are subjected to official certification before being placed on the market, whereas the remaining 80 deal with vegetables seeds, that are subjected to official post control and for which preliminary certification is optional and very rare.

The number of companies dealing with seeds of agricultural plant species is decreasing, being around 360 in 1998/1999. Figures 1 and 2 show the company regional distribution and the licenses for seeds subjected to official certifications, respectively. Cereal (wheat, barley, rice, maize) is the sector mainly represented.

The value of the Italian seed market can be set at around EUR 680- 
700 million, at wholesale level and excluding the incidence of seed treatments (ASSOSEMENTI 2014 estimation). Seeds of vegetables, cereals and maize represent the most important sectors (Figure 3) (ASSOSEMENTI, 2015).

Concerning the seed trade with other countries, the balance is constantly negative in terms of value: over EUR 100 millions in 2014, resulting from an import of about EUR 360 million and an export of about EUR 255 million (ASSOSEMENTI elaboration of official ISTAT data). Figures 4 and 5 represent the main sectors and the value of the seed trade with other countries. For vegetable seeds, imports greatly exceeds exports, and this also stands for maize, legumes and potatoseeds. Forage seed imports are about the same as exports. Rice and sugarbeet seeds are the only two sectors where the value of exports exceeds imports (ASSOSEMENTI, 2015).

Seed growing (multiplication) in Italy concerns many companies and a wide land area. Table 1 outlines the main data. In 2014, seed multiplication was carried out on around 190,000 ha for agricultural plant species, subjected to official certification, and on 26,000 ha for vegetables and herbs, for both internal market and exports (mainly on the

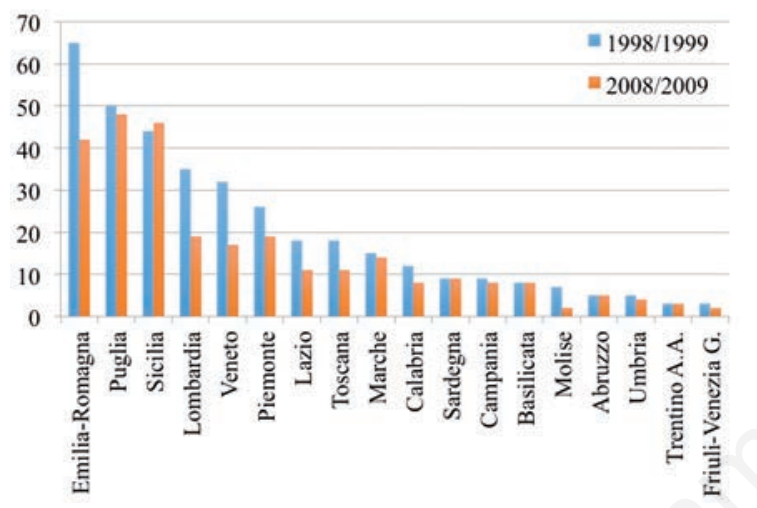

Figure 1. Seed companies in Italy: regional distribution of companies that officially certify seeds of agricultural plant species (source: CRA-SCS data).

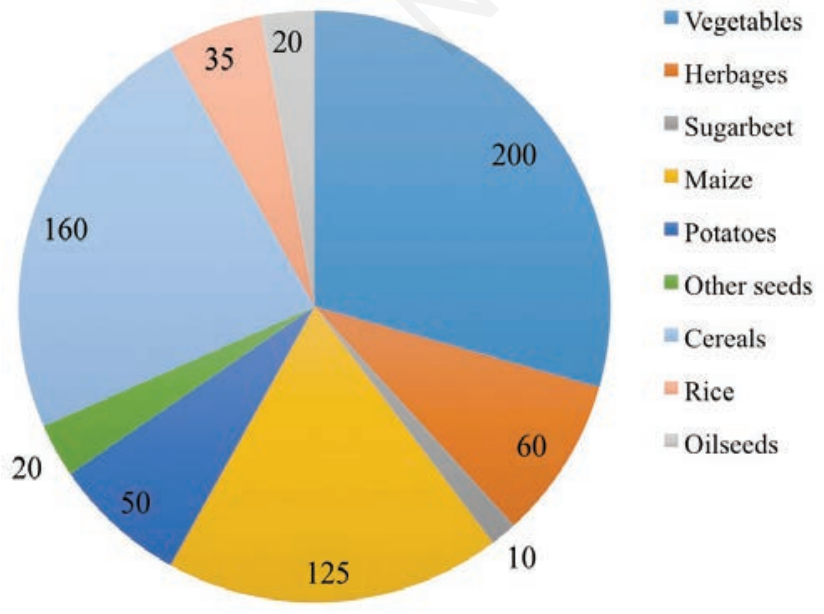

Figure 3. The seed market in Italy in 2014, values in EUR million at wholesale level and excluding chemical seed treatments (source: ASSOSEMENTI estimation).
Table 1. Seed growing surfaces in Italy in 2014.

Species Hectares

Seeds of agricultural plant species

subjected to official certification, of which: In total 189,000

- Durum wheat

$\begin{array}{ll}\text { - Rice } & 8000 \\ \text { - Mearley } & 10,500\end{array}$

- Maize $\quad 7500$

- Sunflower $\quad 1700$

- Sugarbeet $\quad 3500$

- Lucerne $\quad 20,000$

- Clovers $\quad 15,000$

- Ryegrasses 4000

- Legumes $\quad 5000$

Vegetable seeds* In total 14,000

Herb seeds* In total 12,500

Seeds of agricultural plant species in 2014 were grown mainly in the regions of Emilia-Romagna (22\%), Puglia (12\%), Sicilia (10\%), Marche (9\%) and Veneto (8\%). Seeds of vegetable species in the regions of Emilia-Romagna (40\%), Marche (27\%), Puglia (14\%) and Molise (5\%). Source: CRA-SCS data and *ASSOSEMENTI survey.

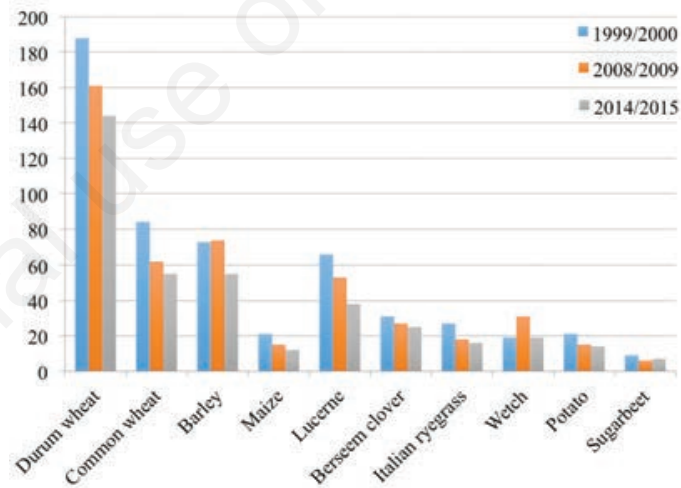

Figure 2. Main sectors of activity in Italy of companies that officially certify seeds of agricultural plant species (source: CRA-SCS data).

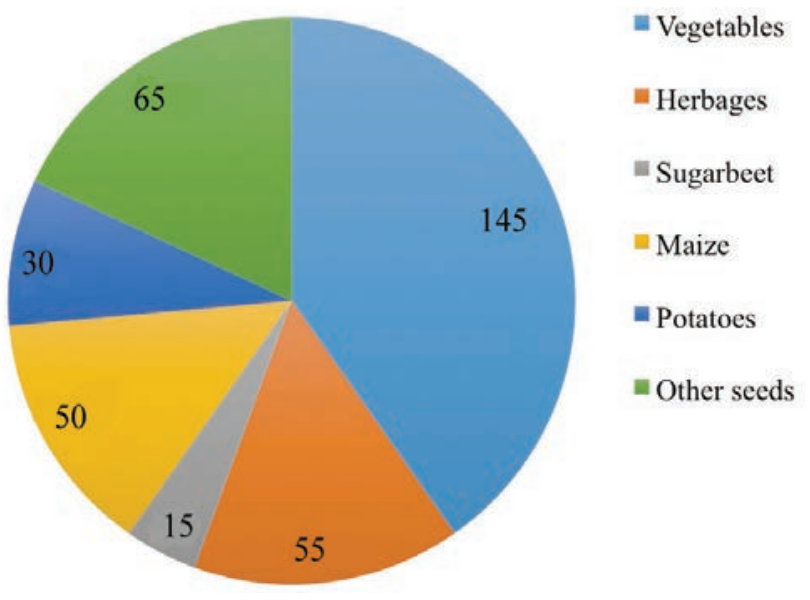

Figure 4. Imports of seeds by Italy in 2014. Values in EUR million (source: ASSOSEMENTI analysis of ISTAT data). 
basis of third party multiplication contract or in the context of relations with mother companies). In addition to seed companies, seed growing in 2014 involved about 14,500 farmers for agricultural plant species and at least another 2500 farmers for vegetable seeds.

In regards to the regional distribution of seed crops, overall, seed growing of agricultural species is carried out more or less in all areas of the country, whereas that of vegetable species is particularly concentrated in the Emilia-Romagna and Marche regions, which are located in the northern and middle area along the Adriatic coast.

The growing of seed crops is a very specialized and profitable activity, capable to integrate the farmers' income. However, it has to be carried out under a cultivation contract, in close cooperation with the seed company owner of the variety or with the provider of pedigree seed.

Production of seeds depends also on agricultural policies and on the grants of direct or indirect subsidies. Figure 6 shows the collapse of production of official certified seeds of durum wheat as a result of the decoupling of common agricultural policy direct payments and the consequent abolition of the compulsory use of certified seeds by farmers to get subsidies.

\section{The evolution of seed activity}

The seed industry has experienced extensive structural changes and transitions. The first companies in Europe date back to 1750-1800s and were specialized in the selection of horticultural crops. However, for decades seed production was hardly developed as a commercial activity: farmers depended essentially on seeds saved from their previous crops and only rarely or in case of need they purchased seed from commercial sources. At the beginning of the 1900 s, with the implementation of modern plant breeding, seed activity marked a first important transition with the multiplication and trade of seeds of varieties developed in the public domain, such as Universities or other Research Institutions.

In Italy, a good example were figures like Francesco Todaro and Nazareno Strampelli with their work in the cereals' sector, that has been at the basis of the creation respectively of the company Società

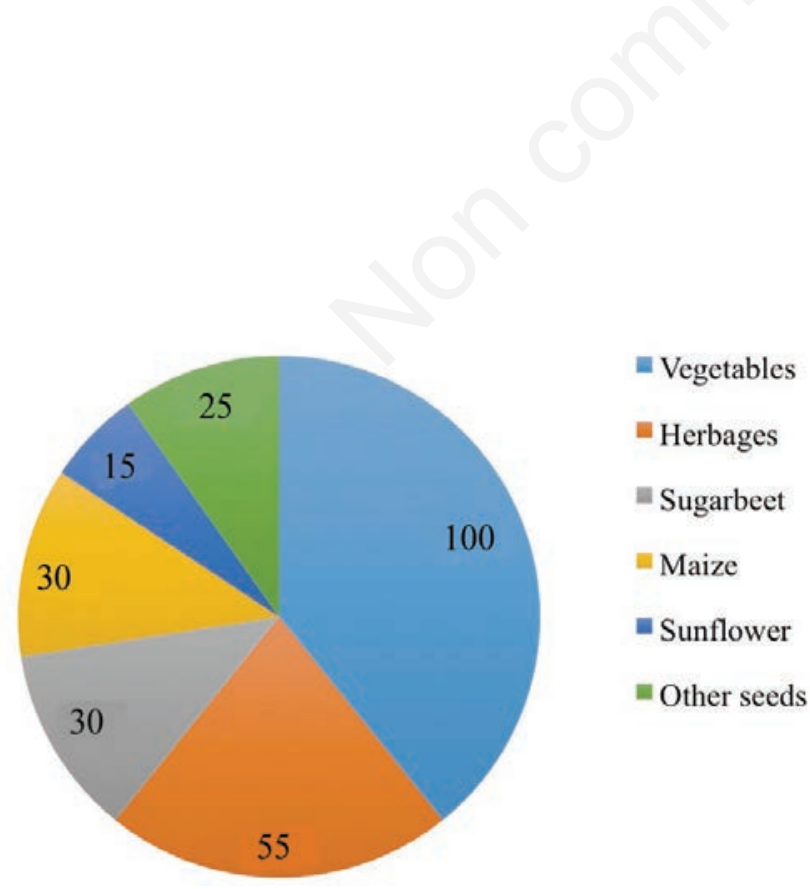

Figure 5. Exports of seeds by Italy in 2014. Values in EUR million (source: ASSOSEMENTI analysis of ISTAT data).
Produttori Sementi (1911) and of the Istituto Nazionale di Genetica per la Cerealicoltura (1919).

Gradually, private seed companies integrated and developed their own plant breeding capabilities. A formidable transition took place around the 1950s with the development and spread of hybrid varieties, starting with maize, for their inherent capacity to protect themselves against non-authorized multiplication and to assure returns to private investments.

The last and still ongoing transition is related to the implementation of modern biotechnologies in plant breeding, since the 1980s with the first genetically modified varieties up to present with the so called new breeding techniques. In this phase, chemical, oil and food industries have entered the seed business, important resources have been allocated to sustain new breeding programs and regulatory steps, and new companies were created through mergers and acquisitions.

The evolution of the seed sector has to be examined also in connection with the existence and evolution of seed policies, at national as well as international levels [ see the European Seed Association (ESA): https://www.euroseeds.eu/vision-document; the International Seed Federation (ISF): https://www.youtube.com/watch?v=0y2XQloPbps (2009); the HFFA Research GmbH (2016): http://www.plantetp. org/images/stories/stories/documents_pdf/HFFA_Research_Paper_03_ 16_final_protected.pdf].

It is worth to recall the implementation of the European seed legislation started in 1966 and based on two fundamental pillars: the compulsory listing of new commercial varieties, after trials to verify their distinctness, uniformity and stability and value for cultivation and use, only for agricultural plant species, and the official certification of seeds before placing on the market. As regards to the intellectual property rights on plants, in 1961 the International Convention for the Protection of New Varieties of Plants (UPOV Convention) was signed. It established an intellectual property protection system, which is different from patents. In fact, the UPOV Convention admits the breeder's exemption (access to previously protected varieties for breeding pur-

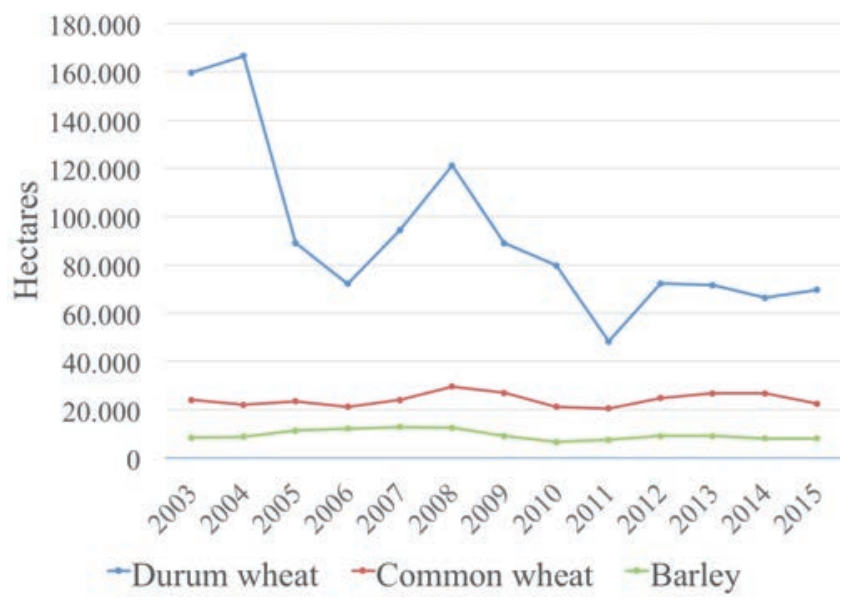

Figure 6. Winter cereal surfaces officially approved in Italy for seed multiplication in the period 2003-2015. The decoupling of direct payments for grain production under the common agricultural policy, introduced with the Fishler reform, EC Regulation No. 1782/2003 (European Commission, 2003), and the consequent abolition of the compulsory use of certified seed to get direct payments, has caused a severe drop in the seed production, in particular for durum wheat. 
poses), as well as the farmer's exemption (right of the farmer to save for propagating purposes, on his/her own holding, the product of the harvest of a protected variety).

\section{Plant breeding and seed industry contributions to agriculture}

There are plenty of studies and analyses showing how the work of breeders and seed companies contribute to agri-food productions, through new varieties with higher yields, better quality, improved useefficiency of resources and reduced environmental impact. Some achievements are cited hereunder: i) higher crop yields: a review of the results obtained through the Italian breeding programs over the last century showed for durum wheat an annual genetic gain in terms of yield ranging from 17 to $24.6 \mathrm{~kg}$ per ha per year (De Vita et al., 2007). In the UK, a similar analysis of historical data from National List trials indicated that, since 1982, for cereal and oil seed rape at least $88 \%$ of yield increase is attributable to genetic improvement (DTZ, 2010; Mackay et al., 2010; ADAS UK Ltd., 2015) [for further reading see also the British Society of Plant Breeders (BSPB): http:/www.plantbreedingmatters.com/sg_userfiles/Sustainability.pdf]. At a global level, between 1985-2005 an increase of $28 \%$ in agricultural production has been observed. The expansion of new cultivated land areas has contributed marginally (less than $3 \%$ ), while more intense use of land (7\%) and yield increase (over 18\%) have given the most important contribution, thus confirming the major role played by genetic improvements of major crops (Foley et al., 2011; Ceriotti et al., 2015); ii) stronger resistance to diseases and pest attack, as well as to abiotic stress, to prevent harvest loss; iii) quality of production more suited to market needs; iv) more efficient use of resources, mainly water and nutrients. It should be noted that the use of higher yielding varieties increases land carrying capacity, which contributes to maintaining uncultivated land thus benefitting biodiversity.

Good and certified seeds also bring to farmers the progress of conditioning technologies used by seed companies, like applications of fungicides and insecticides and treatments to facilitate germination in field.

\section{The case of wheat in Italy}

Each crop has specificities that involve seeds too and should be analysed properly. For example, the wheat sector, one of the most important in Italy, following the main point of this presentation: variety development and seed activities are functional to innovation and sustainability in agriculture, therefore they require full support and fundings.

Concerning the collection and availability of fundings for seed variety development, a comparison between Italy and France's situation is reported in Figure 7, where the Italian gap is apparent, due to a lower area for wheat crops, but also to the lower efficiency of the royalty collection system (Curtis and Nilsson, 2012). Moreover, it is not certain that all royalties collected remain in Italy, normally they are gained by original breeders!

In addition, in Italy royalties are collected only through the sale of certified seeds. Table 2 reports for the main crops the rate of use of non-certified seeds, including real farm saved seed, as well as seeds illegally reproduced and marketed.

The most evident impact is represented by the increase in the national Italian market of varieties obtained through foreign research programs. Figure 8 shows simply, but clearly, how the presence of varieties not bred in Italy has been gradually increasing over time. For common wheat, this presence increases from $3 \%$ in the $1969-1980$ period vs $57 \%$ in the $2000-2010$ period, whereas for durum wheat it increases from $24 \%$ in the $1969-1980$ period $v s 44 \%$ in the $2000-2010$ period.

Farmers and the agri-food industry may not suffer by this situation

\begin{tabular}{|l|}
\hline Elements of evaluation \\
Italy: \\
- Wheat cropped surfaces, \\
about $2,100,000$ ha; \\
- Royalties calculated on certified seeds, \\
approximately EUR 7.5 million/year; \\
- No system in place to collect royalties \\
on farm saved seeds. \\
France: \\
- Wheat cropped surfaces, \\
about $7,800,000$ ha; \\
- Royalties calculated on certified seeds, \\
approximately EUR 50 million/year; \\
- Royalties collected on farm saved seeds, \\
some additionally EUR 10 million/year. \\
\hline
\end{tabular}

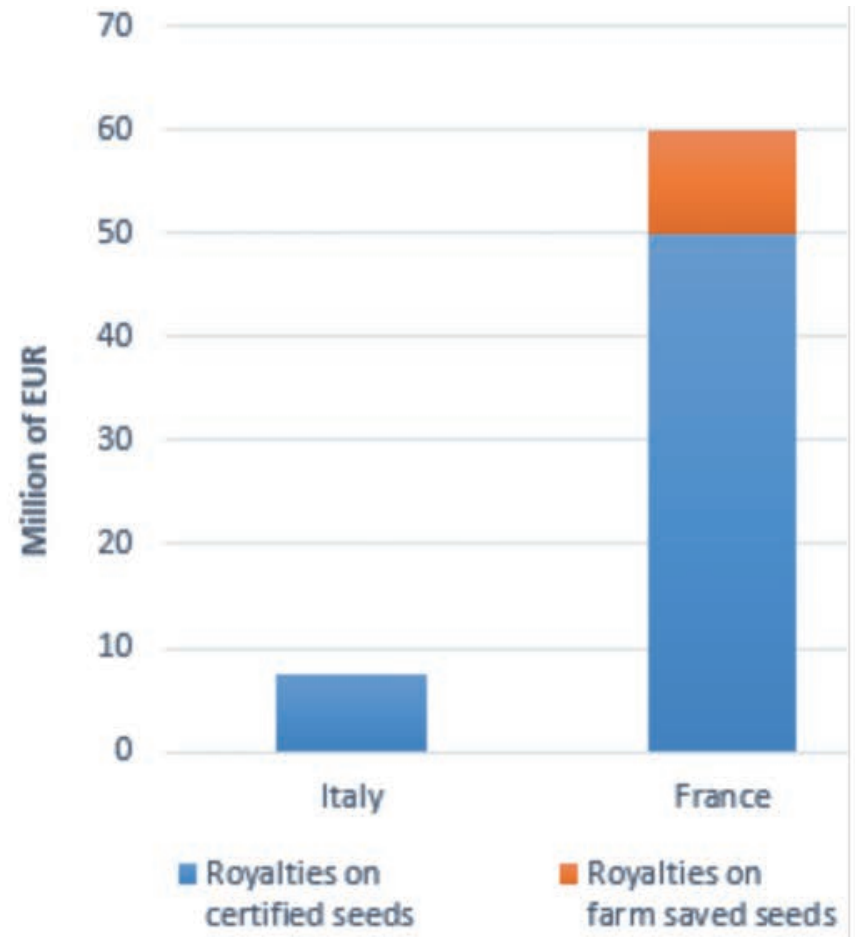

Figure 7. Potential private resources for variety research: a comparison between Italy and France for wheats. 
since other varieties and foreign seed companies are ready to meet market demand. However we should be concerned by the inevitable negative side effects on Italy-based private and public breeding, as well as on the viability of the whole seed sector, including the activity of seed production.

\section{Conclusions}

To ensure that the seed industry can fully play its role as an agricultural innovation driver, some objectives have to be pursued and fulfilled: i) availability of important economic resources to promote and fund research programmes, at any level, private or public. At a time where the use of officially certified seeds is decreasing for those species where open pollinated varieties are mostly used, also because of the decoupling of European farm subsidies no longer linked to the compulsory use of certified seed, the implementation and full respect of plant variety rights (intellectual property) become vital to recover Research and Development (R\&D) costs and foster new investments in variety breeding; ii) increased farmers' awareness of the importance of seeds of good quality and its role for the traceability of productions and as a means of development. This requires the full involvement of farmers and their market organisations to support research and innovation. There are some examples already around us, the closest in France with the so called cotisation volontaire obligatoire on cereals, where, thanks to an agreement between breeders and farmers, a levy currently of 0.70 $€$ per tonne is collected on grain crops [ for further reading see also the Fonds de soutien à l'obtention végétale (FSOV): http://www.fsov. org/index.html; and the Union Française des Semenciers (UFS):http:/ /www.ufs-semenciers.org/actualites/Documents/Reglementation\% 20semences\%20pour\%20diffuser\%20la\%20performance\%20et\%20la\%2 0qualite.pdf]; iii) stronger private/public collaboration in R\&D projects, targeted at practical objectives and with a precise division of tasks. With a European or global vision, cooperation must be extended at this level; iv) clear, fair and rational legislative framework, in combination with a major commitment to prevent and contrast (fight) frauds and illegalities that undermine both externally and internally the development of the whole seed industry.

The statement: The seed of genetically improved varieties already represents today, and even more tomorrow, the highest concentration of technology made available to farmers (Lorenzetti, 1986), delivered

Table 2. Use of non-certified seeds in Italy by farmers.

\begin{tabular}{lc} 
Species & Rate of NCS \\
Durum wheat & $40 \%$ \\
Common wheat & $20 \%$ \\
\hline Rice & $20 \%$ \\
Soybean & $20 \%$ \\
\hline Potatoes & $20 \%$ \\
Lucerne & $40 \%$ \\
\hline Maize & $0 \%$ \\
\hline
\end{tabular}

NCS, non-certified seeds. Source: ASSOSEMENTI estimation, average for 2012 and 2013 crops.
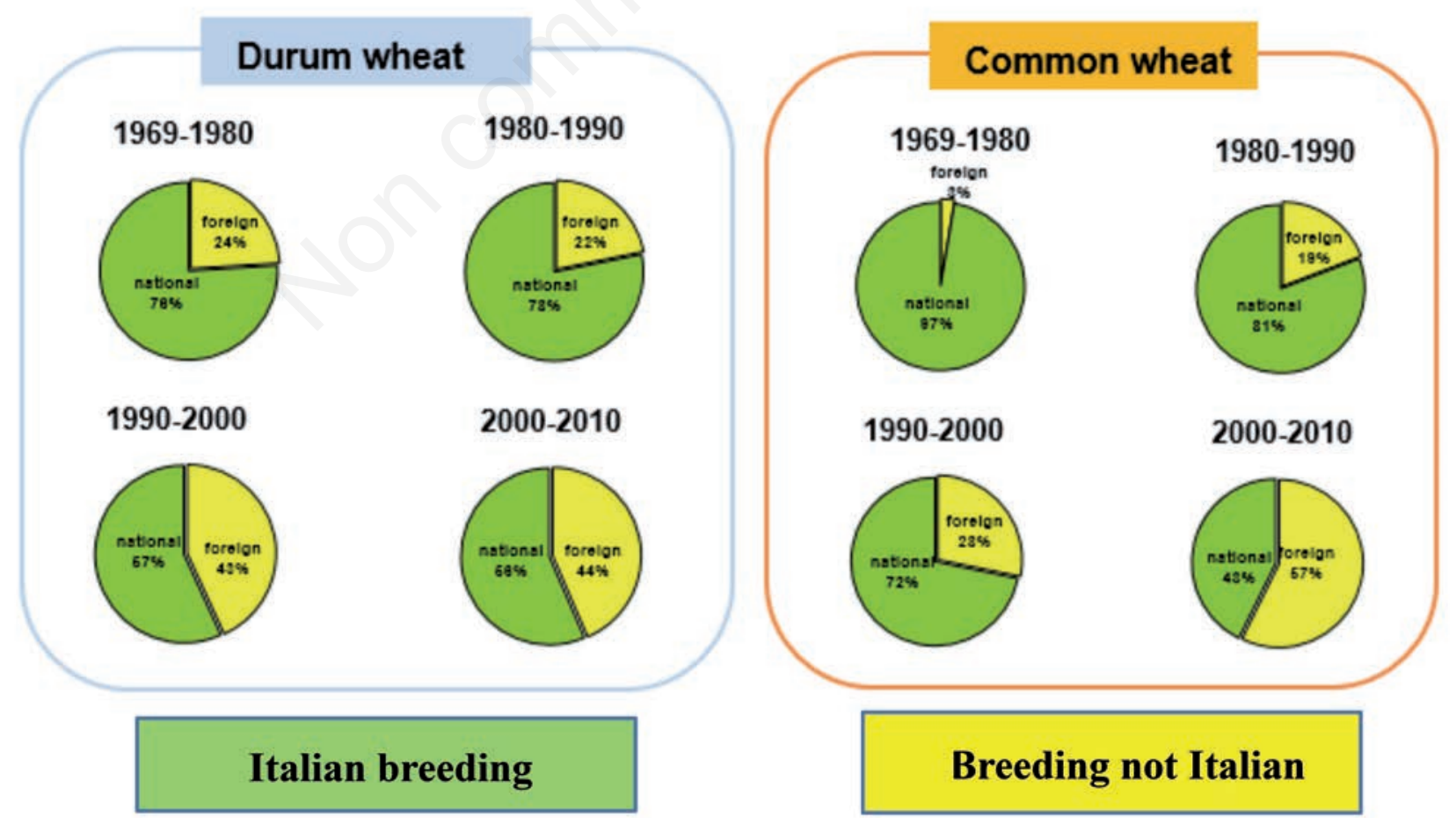

Figure 8. Evolution of wheat varieties on Italian market over last decades (source: ASSOSEMENTI analysis of the country of origin of the new varieties listed in the Italian official catalogue). 
when the omic era was just on the horizon, has been confirmed and will advance in future to meet the demands of a constantly increasing human population.

\section{References}

ADAS UK Ltd., 2015. Review of the objectives of modern plant breeding and their relation to agricultural sustainability. Available from: http://www.bspb.co.uk/sg_userfiles/15-06-01_Review_of_objectives_of_modern_plant_breeding_and_relation_to_agricultural_s ustainability-_Report_Update.pdf

ASSOSEMENTI (Italian Seed Association), 2015. Import export sementi in Italia, 2012-2014. Available from: http://www.sementi.it/statistiche/396/import-export-sementi-italia-2012-2014

Ceriotti A, Tuberosa R, Cattivelli L, Lucas H, CNR for EXPO 2015. Wheat for the future - advancing wheat research for global food security. Available from: https://www.expo.cnr.it/en/node/69

Curtis F, Nilsson M, 2012. Collection system for royalties in wheat: an international study. Bio-Sci. Law Rev. 6:215-38.

De Vita P, Matteu L, Mastrangelo AM, Di Fonzo N, Cattivelli L, 2007. Effects of breeding activity on durum wheat traits breed in Italy during the XX century. Ital. J. Agron. 4:451-61.
DTZ, 2010. Economic impact of plant breeding in the UK. Available from: http://plantbreedingmatters.com/sg_userfiles/BSPB_Impact_ Final_Report.pdf

European Commission, 2003. Council Regulation (EC) No 1782/2003 of 29 September 2003 establishing common rules for direct support schemes under the common agricultural policy and establishing certain support schemes for farmers and amending Regulations (EEC) No 2019/93, (EC) No 1452/2001, (EC) No 1453/2001, (EC) No 1454/2001, (EC) 1868/94, (EC) No 1251/1999, (EC) No 1254/1999, (EC) No 1673/2000, (EEC) No 2358/71 and (EC) No 2529/2001. In: Official Journal, L 270, 21/10/2003, pp 1-69.

Foley JA, Ramankutty N, Brauman KA, Cassidy ES, Gerber JS, Johnston M, Mueller ND, O'Connell C, Ray DK, West PC, Balzer C, Bennett EM, Carpenter SR, Hill J, Monfreda C, Polasky S, Rockström J, Sheehan J, Siebert S, Tilman D, Zaks DPM, 2011. Solutions for a cultivated planet. Nature 478:337-42.

Italian Regulation, 1971. Legge 25 novembre 1971, n. 1096. Disciplina dell'attività sementiera. In: G. U. n. 322, 22/12/1971.

Lorenzetti F, 1986. Seed as a factor in the progress of Mediterranean agriculture. pp 94-105 in Proc. ICARDA/EC Workshop, 16-18 December, Cairo, Egypt.

Mackay I, Horwell A, Garner J, White J, McKee J, Philpott H, 2010. Reanalysis of the historical series of UK variety trials to quantify genetic gain and variety sensitivity. Theoret. Appl. Genet. 122:22538 . 